\title{
Religious Identity in the Use of Social Media Within Pontianak Muslim Community
}

\author{
Zaenuddin Hudi Prasojo \\ Institut Agama Islam Negeri Pontianak \\ email: zaestain@yahoo.com \\ Muhammed Sahrin bin Haji Masri \\ Universiti Islam Sulthan Sharif Ali Brunei Darussalam \\ email: sahrin.masri@unissa.edu.bn \\ Ahmad Fauzi \\ Institut Agama Islam Negeri Pontianak \\ email: arafah98@gmail.com \\ Nur Rahmiani \\ Institut Agama Islam Negeri Pontianak \\ email: nur.rahmiani02@iainptk.ac.id
}

\begin{abstract}
Social media plays a very important role in shaping the identity and trends in todays world. Not only for the young generation, almost all people in every generation have also been "addicted" to social media for their daily need and in other processes through assimilation and integration and building new networks in their communities through online and offline activities. As a result, the emergence of the social media as a medium of communication and information today has many impacts on changes of social structure including the religious identity of its users. This article explores the tendency for the development of religious identity in social media among the Ponianak Muslim community by focusing on the typology of social media users among Pontianak Muslims and various trends in the religious identity of its users. The work suggests that social media users in the
\end{abstract}


Pontianak Muslim community have three main typologies, namely NetPublisher, NetWorker, and NetAdvocate. And the religious identity tendency of social media users in Pontianak is constructed through religious narratives dominated by conservativism discourses. They are seen through at least three aspects including the tendency of religious affiliation, various religious issues that are often discussed, and responses to trending religious issues in social media by Pontianak Muslim netizens.

[Media sosial menempati peran yang sangat penting dalam membentuk identiats dan trend kehidupan di sunia saat ini. Tidak hanya pada generasi muda, sosial media juga telah menjadi candu bagi semua eleman masyarakat dari semua hamper semua generasi dalam rangka memenuhi kebutuhan hidup maupun proses-proses lainya melalui asimilasi dan integrase dan dalam rangka membangun jaringan-jaringan baru dalam komunitas-komunitas mereka baik dalam kegiatan-kegiatan yang bersifat offline maupun yang online. Oleh karena itu, kemunculan media sosial sebagai sarana komunikasi dan informasi hari ini memiliki dampak pada perubahan-perubahan struktur sosial termasuk identitas keagamaan para penggunanya. Artikel ini mengeksplorasi kecenderungan perkembangan identitas keagamaan para pengguna media sosial pada masyarakat Melayu Muslim di Kota Pontianak dengan menfokuskan pada tipologi pengguna media sosial dan kecenderungan identitas keagamaan mereka. Dapat disimpulkan dalam tulisan ini bahwa ada tiga macam tipologi pengguna media sosial pada masyarakat tersebut yaitu yang disebut dengan NetPublisher, NetWorker, and NetAdvocate. Selain itu, identitas keagamaan yang muncul pada para pengguna media sosial pada komunitas Melayu Muslim Pontianak ini didominasi oleh narasi keagamaan yang konservatif. Narasi-narasi konservatif tersebut dapat dilihat pada afiliasi keagamaan, isu-isu keagamaan yang didiskusikan dan respon mereka pada isu-isu hangat di media sosial oleh Nitizen Muslim.]

Keywords: religious identity; social media; Pontianak Muslim community

\section{Introduction}

The development of information and communication technology in modern society is a necessity. Various facilities are available along with the development of technology and 
communication devices with various kinds and functions. One of the recent developments in information and communication technology that is very useful to the world community today is the growing trend of using "social media". In the past, people had a one-way communication, and it was very conventional. The emergence of 'social media' has changed the communication trends of the modern world where communication is not only one way but can involve many people with the facilities and advantages offered by the new media. People not only receive the content in the media, but they can also create content using social media. ${ }^{1}$

Another advantage of social media is that it has a positive impact on the education and teaching process. According to Bennett ${ }^{2}$, academics respond well to the use of social media in the student learning process. They can encourage and provide more motivation for students through the use of social media. Social media also affects the process of shaping youth identity, especially when experiencing a transition period when entering the tertiary level as reported by Thomas et al. ${ }^{3}$ In the study, it was concluded that social media had an extraordinary impact on the process of transitioning the younger generation when entering university. Social media has become a means for assimilation and integration when they enter their new community at the university level, both in online and offline activities, such as getting to know a new community, finding new friends. In other words, the presence of social media has eliminated the boundaries of space and time.

One of the other impacts of social media is the transformation of one's diversity resulting from the presence of social media and smartphones. In the past, religion was something private and not worth

${ }^{1}$ Errika. D. S Watie, "Komunikasi Dan Media Sosial," The Messenger 3, no. 1 (2011): 69-75.

2 "Social Media, Academics' Identity Work and the Good Teacher," International Journal for Academic Development 22, no. 3 (July 2017): 245-56, https://doi.org/ 10.1080/1360144X.2017.1305961.

3 "Understanding Social Media and Identity Work in Young People Transitioning to University," Computers in Human Behavior 76 (2017): 541-53, https://doi.org/https: //doi.org/10.1016/j.chb.2017.08.021. 
talking about in public space. Today, however, when smartphones and social media are increasingly developed, one's religious practices have become more flexible under religious content or narratives that he gets from using social media or smartphones ${ }^{4}$. The presence of social media has also shaped the identity and religious character of its users in accordance with the content they consume from social media.

The earlier mentioned fact is certainly very relevant to the socio-political conditions faced by modern society today. Along with the development of communication and information media, including social media, people expose their life expressions on social media, including religious expressions. ${ }^{5}$ Social media often becomes a vehicle for contemporary religious discourses such as rejection of mass organizations or religious discourses such as the rejection of the Liberal Islamic Network in Bandung, which was inspired by the hashtag \#IndonesiatanpaJIL on Twitter. ${ }^{6}$ In the latest case of rejection of the Nusantara Islamic discourse, it was raised by a particular group of mass organizations using social media as a propaganda tool. Social media has also become one of the most effective means of communication for radical groups or even terrorist organizations. This argument is in line with what Bertram ${ }^{7}$ stated that the emergence of social media dramatically benefits terrorist organizations in their efforts to carry out their mission. Social media becomes a means of

4 Mite Setiansah, "Smartphonisasi Agama: Transformasi Perilaku Beragama Perempuan Urban Di Era Digital," Komunikasi 10, no. 1 (2015): 1-10.

${ }^{5}$ Nadrawina Isnin, "Social Media, Religion, Gender and Politics in Malaysia: A Case of the Social Media Usage by Sarawak Muslim Female Candidates in Batang Sadong and Batang Lupar in the 2018 Malaysian General Election," Al-Albab; Vol 7, No 2 (2018): 161-176 DO - 10.24260/Alalbab.V7i2.1114, December 1, 2018, http://jurnaliainpontianak.or.id/index.php/alalbab/article/view/1114.

6 Imam Ardhianto, "Kontra Publik Keagamaan Dalam Media Baru: Islam, Kebudayaan Populer, Dan Media Sosial Pada Gerakan \#IndonesiaTanpaJIL," Antropologi Indonesia, no. 2 (2016): 83-102.

7 "Terrorism, the Internet and the Social Media Advantage: Exploring How Terrorist Organizations Exploit Aspects of the Internet, Social Media and How These Same Platforms Could Be Used to Counter-Violent Extremism," Journal for Deradicalization, no. 7 (2016): 225-52. 
communication among terrorists to launch cyber attacks and spread their propaganda messages with a broader audience.

Muslim communities in Pontianak also enjoy the rapid development and use of social media. The emergence of various religious discussion groups on social media with various issues discussed is an indicator that the Pontianak Muslim community actively participates in discussing various current religious issues. Therefore, this article aims to find out the typology of social media users in the Pontianak Muslim community as well as various religious identity trends that are developing among Muslim users of social media.

\section{Methods}

Based on qualitative research data, the article focuses on the use social media by Malay Muslim users os social media in Pontianak City with the support of daya analysis following the process provided by previous scholars. ${ }^{8}$ It focuses on the most famous social media including Facebook, Twitter and Instagram. Some supporting reasons include that, first, those social media have been found to be the most familiar among the Malay Muslim users in Pontianak. Second, the most available data related to the issue being observed found in those types of social media. Third, the authors find that the access to the data provided by the key informants is supported by those three most familiar types of social media.

Data is collected from two main sources including informants, documents available in the social media accounts and other supporting document available both online and offline from the Malay Muslim users of the social media. Data was carefully collected through three techniques that are common in qualitative studies, namely observations, in-depth interviews, and document review. Observations

\footnotetext{
${ }^{8}$ J. Atkinson, "Qualitative Methods Book Title : Journey into Social Activism Book Subtitle: Qualitative Approaches This Chapter Explores:," Journey into Social Activism, 2017, 27-64; Kerstin Stenius et al., "How to Write Publishable Qualitative Research," Publishing Addiction Science: A Guide for the Perplexed, 2017, 155-72, https://doi.org/10.5334/bbd.h.
} 
by directly observing the available online accounts of social media was significantly helpful. Document review was used to collect information on concepts related to the substance of the research project, including identity, statements and information on religious issue and social interaction on media. All data was analyzed using qualitative approach for necessary argumentations and conclusions supported by appropriate references.

\section{Results}

\section{Social Media as a Means of Religious Identity Building}

The emergence of new media, in this case, social media, has become a trend in the current era of globalization. New media such as smartphones and social media have a significant impact on all activities of human life, including various patterns of social interaction that they experience as a result of using these new media. This case is in line with what Situmorang ${ }^{9}$ and Fitriani ${ }^{10}$ reported that the internet has been used by all sciences, therefore utilizing related to many areas of human life. In this paper, the use of the Internet is limited in politics, business, education and socio-culture. That being said, the various new media on the Internet are almost all utilized by these four fields. The intended use is for positive purposes even though in practice, the Internet is also used for negative activities by a small number of Internet users. Social networking sites and video sharing sites often affect the lifestyles of Internet users and the material uploaded to both media is also easy to reach the wider community, for example via mobile phones which most of the people already have. Due to the rapid use of electronic media, primarily social media, the government uses the ITE Law to deal with the misuse in the dissemination of information through electronic media, including social media.

\footnotetext{
9 "Pemanfaatan Internet Sebagai New Media Dalam Bidang Politik, Bisnis, Pendidikan Dan Sosial Budaya," Administrasi Bisnis 8, no. 1 (2012): 73-87.

10 "Analisis Pemanfaatan Berbagai Media Sosial Sebagai Sarana Penyebaran Informasi Bagi Masyarakat," Paradigma - Jurnal Komputer Dan Informatika 19, no. 2 (October 2017): 148-52, https://doi.org/https://doi.org/10.31294/p.v19i2.2120.
} 
Ardhianto ${ }^{11}$ provided an example of the influence of how the presence of new media and smartphones is very significant in the formation of one's religious opinion. According to him, religious identity and popular culture influence each other because the two often come across in the same medium and private space. The phenomenon of \#IndonesiaTanpaJIL shows symptoms that can explain how religious practices are presented in the form of a mixture of texts, discourse, symbolic material and popular culture.

Another study by Holik ${ }^{12}$ reported that the presence of the internet, especially social media in the Indonesian demographic domain, has had an extraordinary impact. Social media provides a public space that gives people the freedom to express their aspirations by utilizing social media facilities. In fact, it is not uncommon for discourses circulating in social media-based public spaces to turn into real political actions. From these findings, it has been known that the presence of social media and popular culture is often used as a means to mobilize public opinion against certain religious groups that are considered 'heretical' through the distribution and use of hashtags on social media.

Besides, social media can also shape the religious behaviour of its users, such as the findings from Setiansah ${ }^{13}$ showed that the development of smartphones had encouraged the growth of religious practices of its users. They use the smartphone media in religious life, such as searching and spreading religious information, religious practices, and the formation of religious habitus. Moreover, the resistance of religious identity is inherent in urban women. Also, Putri ${ }^{14}$ revealed that the presence of social media had become a haven for the development of popular Islamic discourse brought by social

11 Ardhianto, "Kontra Publik Keagamaan Dalam Media Baru: Islam, Kebudayaan Populer, Dan Media Sosial Pada Gerakan \#IndonesiaTanpaJIL."

12 "Teknologi Baru Media Dan Demokratisasi Di Indonesia," Jurnal Makna 1, no. 2 (2011): 41-57, https://doi.org/https://doi.org/10.33558/makna.v1i2.1060.

${ }^{13}$ Setiansah, "Smartphonisasi Agama: Transformasi Perilaku Beragama Perempuan Urban Di Era Digital."

14 "Wacana Islam Populer Dan Kelahiran Ustaz Medsos Di Ruang Publik Era Digital," Jurnal Komunikasi Dan Kajian Media 2, no. 1 (2018): 87-114. 
media missionaries. One of them is Felix Siauw. The preacher who is a convert preaches religious teachings in accordance with his belief through posts on social media, one of which is Instagram through the @ felixsiauw account. Islamic discourse in accordance with the Sharia then developed rapidly and increasingly dominated the cyberspace which can be seen from the comments on Felix Siauw's posts based on religious understanding netizens. Social media, according to Khamdan and Wiharyani ${ }^{15}$ also helps to exacerbate identity-based political polarization. This exploration happens because social media has become a means of communication and dissemination of information and discourse in the political arena at the time. Social media provides space to include freedom of expression in political views. In addition, it is also able to shape the political perceptions of its users. As Hasfi, et a ${ }^{16}$ stated about the representation of leadership on Twitter as a social media platform. Twitter is a media for leaders to create an image, also known as the use of Imagology politics. It usually utilizes symbols that are attached to prospective leaders such as Muslims, Javanese, Natives, and many more. Symbolic values then represent the images that determine the choice of Twitter users.

Hoaxes also arise due to the use of social media as reported by Rahadi ${ }^{17}$ that fabricated information is deliberately made to influence the public and is increasingly rife due to stimulant factors such as socio-political issues and SARA (Ethnicity, Religion, Race and InterGroup Relations). Other findings as revealed by Pakpahan ${ }^{18}$ also showed that the presence hoxes in Indonesia is inseparable from the emergence of new media such as the widespread use of the internet and social media, which in turn leads to anxiety and conflict.

15 "Mobilisasi Politik Identitas Dan Kontestasi Gerakan Fundamentalisme," AlTahrir 18, no. 1 (2018): 193-218.

16 Nurul Hasfi, Sunyoto Usman, and Hedi Pudjo Santosa, "Representasi Kepemimpinan Calon Presiden Di Twitter," ASPIKOM 3, no. 2 (May 2017): 270-84.

${ }^{17}$ Dedi Rianto Rahadi, "Perilaku Pengguna Dan Informasi Hoax Di Media Sosial," Jurnal Manajemen Dan Kewirausahaan 5, no. 1 (June 2017): 58-70.

18 Roida Pakpahan, "Analisis Fenomena Hoax Di Media Sosial Dan Cara Menanggulangi Hoax," in Konferensi Nasional Ilmu Sosial Dan Teknologi, 2017, 479-84. 
Therefore, hoaxes need to be addressed through the behaviour of the community itself; that is, the community is expected to be smart in using technology, wisely responding to the current information. Widespread use of sarcasm as a means of spreading hate speech on social media has also become widespread, as reported by Nugrahani (2017). According to her, the use of narratives on social media is often not on target and seems distorted. The use of deviant language discussed in this paper is the use of language or narrative sarcasm intended to convey utterances of hate, insults, humiliation, demeanour, verbally attacking people who are disliked on social media.

It is clear that the presence of new media, including the internet and social media, has an extraordinary impact, especially on religious conversations. Religion as revealed by Abdullah ${ }^{19}$ has shifted into an object of daily conversation with a diverse and contestation meaning process, no longer being absolute and elitist. The shift of the centre of religious knowledge from a figure who constructs religion in a topdown manner into the public has brought fundamental implications to the development of religion itself. Various conflict and hoaxes that occur in a religious discourse on social media have a negative impact. As stated by Simangunsong ${ }^{20}$ that in the use of social media, the direction of the relationship from nonintimate to intimate does not occur properly. Individuals tend to be arbitrary in issuing a statement regardless of whether the statement is a statement that encourages individuals to learn or get information and knowledge from their thoughts. They even attack and harass someone's identity. This narration indicates individual weaknesses in literacy using social media itself.

Several previous studies have sufficiently provided compelling arguments that social media has actively been used in forming the

19 "DI BAWAH BAYANG-BAYANG MEDIA: Kodifikasi, Divergensi, Dan Kooptasi Agama Di Era Internet," Sabda: Jurnal Kajian Kebudayaan 12, no. 2 (December 2017): 116-21, https://doi.org/https://doi.org/10.14710/sabda.12.2.116121.

20 Benedictus A. Simangunsong, "Interaksi Antarmanusia Melalui Media Sosial Facebook Mengenai Topik Keagamaan,” ASPIKOM 3, no. 1 (2016): 65-76. 
religious identity of its users. This case is undoubtedly fascinating because so far, a person's religious identity is often shaped through the process of education and religious understanding that is transmitted and received through religious institutions or formal religious activities. Moreover, with the circulation of hoaxes and various false narratives, the negative impact on the use of social media is on the rise, especially from the findings of the development of the religious identity of the users of social media as previously stated that there is a tendency that religious values developed in social media seem to lead to fundamentalism and conservativism. This phenomenon is, in fact, threatening, especially in the development of religious studies discourses in Indonesia, including the strengthening of inter-religious sentiment through the organizations and mass mobilization in social media.

Whereas in the context of civil society as stated by Mujahidin ${ }^{21}$, religion can become an obstacle to civil society if it offers exclusive values and promotes subjective truth. Therefore, pluralism becomes a necessity in diversity. In the context of Indonesian society, for example, religious expressions appear in its scope. This argument is in line with the view of Bashori (2015), who stated that Islam is a universal religion that has the consequence of very high appreciation for the existence of local culture. Through Nusantara Islam, Islam and culture then acculturate and form a variety of religious expressions. Islam also highly values plurality and religious pluralism. According to Sayyid Hosen Nasr in Rahman ${ }^{22}$ Islam has two dimensions, namely the exoteric and esoteric dimensions. The exoteric dimension is the practice of Sharia which allows each different religion, whereas in the esoteric dimension is marked by good inter-religious relations. A person can create pluralism as part of God's Grace if the physical dimension of religious teachings (Islam) is also manifested in the outer dimension, namely in social life, primarily in interfaith life. This manifestation is because God's oneness does not limit creation to only

21 Anwar Mujahidin, "Umat Beragama Sebagai Masyarakat Beradab: Identitas Agama VS Kebangsaan,” Jurnal Kalam 9, no. 1 (2015): 17-30.

${ }_{22}$ M.Syaiful Rahman, "Islam Dan Pluralisme," Fikrah 2, no. 1 (2014): 401-18. 
one religion but many variations which are part of the diversity of God's attributes.

Religious fundamentalism in social media also leads to the weakening of religious authority today due to the rapid development of social media, as revealed by Sholikhin. ${ }^{23} \mathrm{He}$ argues that people can easily learn and look for information related to religious issues. Information that was previously only accessible through books or by studying in Islamic Boarding Schools (pesantren) can now be easily accessed on Google. This information technology also allows a person to become a mufti or kyai or ulama without having to study religion for decades. Theoretically, this information shows the existence of fragmentation of religious authority, not only in Indonesia but also throughout the world and religious traditions.

\section{Typology of Social Media Users in Pontianak Muslim Community}

Muslim social media users in Pontianak also enjoy the emergence of social media in the community. Although, as far as the authors' observations are concerned, there is no sufficient research to present data on the percentage of social media users among the Pontianak muslim community, there are some relevant studies that present some data on social media users in Pontianak. One of them is a study conducted by Susilo. ${ }^{24}$ This study concluded that there are more Facebook-only users than Instagram-only users or use of both social media platforms combined, and $63 \%$ of social media users are not yet married with an average level of activity or 2-4 times of access each day.

In general, social media users in Pontianak can be seen from their various activities in the use of social media that displays religious

\footnotetext{
${ }^{23}$ Ahmad Sholikhin, "Gerakan Politik Islam Di Indonesia Pasca Aksi Bela Islam Jilid I, II Dan III," MADANI 10, no. 1 (2018): 12-33.

${ }^{24}$ Budi Susilo, "Pemasaran Digital: Segmentasi Demografi Pengguna Media Sosial Di Kota Pontianak," Jurnal Eksplora Informatika 8, no. 1 (2018): 69-79, https://doi.org/https://doi.org/10.30864/eksplora.v8i1.163.
} 
identity in each of their posts. According to Wahyudi ${ }^{25}$, netizens can be divided into three groups, namely: 1). Negative, i.e. internet users who tend to see that the internet has many negative sides and is not good for the family. Psychographically, they tend to be conservative, and have traditional views; 2). Moderate, i.e. users who use the internet according to their needs. For them, the internet is a source of information and at the same time, a means of entertainment; 3 ). Positive, i.e. users who use the internet so as not to miss the trend. For them, the internet is everything, an inseparable part of their lives.

Whereas based on internet and social media user profiles, netizens can be divided into several typologies as follows: 1). users who actively spread negative aura to the public by using internet media. The reason to connect to the internet from the beginning is for nosy and negative things; 2). Sceptical users who love to hate. They thrive in forums because they can comfortably appear without a real name. With this anonymity, they can move freely to do nosy things on the internet; 3). Netavoiders, sceptical internet users who think of the internet as having much negativity, so they do not stay online for long. They use the internet to satisfy their curiosity or because they have to. In terms of activities, they are passive internet users, merely watching things in the online world; 4). NetPublishers, internet users who use the internet as a medium to broadcast their existence to the public. The internet is seen as limited to a means that suits their interests and needs. Rationally, they see that it is important to exist on the internet; 5). NetWorkers, internet user who are common people connected to the internet rationally only for Facebook, Twitter, buying and selling on Kaskus, joining LinkedIn, and using other social media platforms so that they can refresh and expand their network; 6). NetCrawlers, internet users who rationally regard the internet as important. However, because they are still learning to crawl how to use the internet for their interests and needs, they are still at the stage of becoming ordinary viewers in the online world. 7). NetAdvocates,

${ }^{25}$ Hijrah Wahyudi, “Analisis Faktor-Faktor Yang Dipertimbangkan Netizen Dalam Melakukan Transaksi E-Commerce Di Kota Pontianak," Jurnal Eksos 10, no. 1 (2006): 32-44. 
influencer internet users, true internet fighters, having idealism about openness, equality, freedom of speech and extraordinary enthusiasm, and the ability to convey their ideas to the public; 8). NetJunkies, internet users who are common people using the internet positively with their communities in the online world. Most of them have names and networks in cyberspace. And; 9). NetRookies, newcomers to the internet world, new to the internet and their surfing hours on the internet are still limited. They aspire to become a NetJunkie so they can build a character known by people in the online world.

Pontianak Muslim Community often uses social media for certain motives and interests. Some only share information about religion such as majelis taklim, Qur'an recitals or tabligh akbar spread by social media accounts such as the NU Facebook fan page, the official account of Asy-Syarobut Thohur, LPD al-Bahjah IV, Habib Thoha Bin Husain al-Jufri, MCR ar-Ridho, Subuh Akbar Kalbar as well as several other official social media accounts. In addition to Islamic-based activities, the social media accounts above often present Islamic discussion using Video Live Streaming media with certain themes or recitals and sermons in certain places in Pontianak and its surrounding areas. Typologically, this phenomenon shows that Pontianak Muslim netizens fall into the NetPublisher typology where they use social media as a means of dissemination and publication of religious activities both personally or through accounts that have a quite large number of followers in Pontianak.

The above phenomenon also shows that many Pontianak preachers use social media as a means of promoting their preaching activities. For example, the Facebook fan page of Habib Thoha Bin Husain al-Jufri (Habib Thoha al-Jufri) caregiver of Majelis AsySyarobut Thohur has so far got 11,281 likes. In comparison, the Facebook fan page account of the Cinta Rasul ar-Ridho account managed by the MCR ar-Ridho under the supervision of al-Habib Abdullah Ridho ibn Yahya has got more than 2000 likes. Both are among the many Pontianak scholars who are quite active in using social media as a means of preaching, from publicizing the agenda of the assembly activities, fostering words of wisdom in the form of 
memes and infographics and publication of studies in the form of video streaming in each program of the assembly, or Qur'anic studies they conduct.

The phenomenon of social media propaganda among Pontianak Muslim netizens can also be seen from the emergence of some propaganda media fan page such as the NU Khatulistiwa, Dakwah Khatulistiwa, and Subuh Akbar Kalbar. These da'wah media actively provide information about preaching content that comes with through memes, infographics, videos and short narratives. Besides, this media is also a means of propaganda of various Islamic discourses attached to the da'wah media affiliation, so that more or less the presence of the media influences Muslim netizens who actively participate in and interact with the media. This conspiration is certainly interesting to observe and in reality with the context of da'wah in today's modern era as stated by $\mathrm{Basit}^{26}$ that one of the four factors that need to be considered in the development of da'wah in the modern era is the mastery of information technology by the preachers or certain religious communities and make preaching no longer traditional.

There are also local accounts that are quite concerned about bringing "Malay" and "Islamic" identities in particular in responding to various issues that have occurred lately. One of them is the Facebook account "West Kalimantan Muslim and Malay Community Alliance" or "Malay People's Association of West Kalimantan" which is quite active in spreading the agenda of Defend the Ulemas action in Pontianak when the viral persecution was carried out by a group of people against some quite famous figures in the media namely Felix Siaw, Bachtiar Nashir and Abdus Somad. Thus, Pontianak Muslim Netizens can be categorized into at least 3 groups. First, NetPublishers, i.e. those who see the importance of showing their existence in cyberspace including social media through religious posts; Second, Networkers, i.e. those who only use social media as a means to connect; and third, Netadvocates, i.e. those who consciously make the internet and social media a means to promote their ideas and thoughts.

\footnotetext{
26 “Dakwah Cerdas Di Era Modern,” Jurnal Komunikasi Islam 3, no. 1 (June 2013): 76-94, https://doi.org/10.15642/jki.2013.3.1.\%p.
} 


\section{Discussions}

Pontianak Muslim Community consists of various ethnic groups. The majority is Malay, while the rest are migrant ethnic groups such as Javanese, Madurese, Bugis, Sundanesse and Banjarese. In the context of the use of social media, it is quite difficult to trace their religious identities considering the lack of data on the number of accounts and users of social media in this city. However, in this article, the researcher attempted to trace their religious identity, randomly selected from the leading social media accounts, especially on Facebook, which openly mentions "Pontianak" and "Islam". In this section, the religious identity of the Pontianak Muslim community would be focused on three aspects, namely religious affiliation, religious narratives being discussed and the response to religious issues that are becoming a trend on social media.

\section{Religious Affiliation}

Religious affiliation is closely related to religious preferences and references followed by an individual. In the context of religious discourse on social media, seeing the social affiliation of social media, netizens become a necessity to identify various religious discourse trends discussed in social media. A person who is affiliated with a particular religious group would undoubtedly have a lot of religious discourses influenced by the organizations he is affiliated. In the context of Muslim society, many social media users in Pontianak, in general, openly declare affiliation of religious organizations as a reference in taking sources that they consider authoritative in religious matters. The Facebook account "Nahdliyin Pontianak", for instance, is quite active in sharing posts originating from websites or pages affiliated to the Nahdlatul Ulama organization. Another account that is also quite active is the "Dakwah Khatulistiwa" account which actively shares posts from social media accounts originating from Hizb utTahrir Indonesia (HTI) or similar organizations.

The "Nandar Rezky Ramadhan" account is one of the Facebook accounts that uses his real name, Nandar Rezky Ramadhan, 
a founding activist and secretary-general of the Malay People's Association (POM). This ethnic group-based organization is quite active in campaigning for the nobility of Malays in West Kalimantan. The POM is often involved in various actions triggered by religious sentiments such as Islam and Ulema actions. They also use Facebook Fanspage and Facebook Groups to promote their cause. This account has 3110 followers, and their Facebook group has more than 21 thousand accounts. It is quite challenging to trace the affiliations of users who openly share posts from these POM activists. But looking at the trends and narratives that are often responded by the POM, it can be seen that the majority of POM supporters and activists are often affiliated with movements such as the Islamic Defenders Front (FPI), Hizbut-Tahrir Indonesia (HTI) and other fundamentalist movements. It is unsurprising that when there are issues that concern the national Islamic movements, the POM readily mobilizes the mass through social media to respond to such issues. In contrast, "Qodja Galata" an account belonging to Abdul Qadir Jailani, one of the 'coffee hall' activists represents Pontianak Muslim netizens who are quite "moderate" in each of their posts. The man who claimed to be a former tarbiyah (education) activist and had been active in HTI openly criticizes the religious behaviour of the previously mentioned groups.

The religious affiliation of Muslim social media users in Pontianak is quite diverse. This statement can be seen from several trends: first, accounts that openly display the identity of their religious affiliation such as with mass organizations and religious beliefs; second, accounts that do not explicitly display their affiliation, but their religious affiliation can be seen from various posts and their interactions on social media. In general, the religious affiliation of Pontianak Muslim netizens can be categorized in two models of affiliation. First, netizens' religious affiliation related to certain religious organizations such as Nahdlatul Ulama, Islamic Defenders Front, Hizbut-Tahrir Indonesia, and others. Second, a religious affiliation that is closely related to specific ethnic groups, such as the Malay People's Association (POM) which often attaches Islamic and Malay identities on various posts. As is known, POM is an ethnic 
group-based organization that brings together the Malays, especially in West Kalimantan from various backgrounds, ages, genders and social strata. As quoted by Zulham ${ }^{27}$, among the objectives of the POM's formation are to elevate and preserve the Malay culture in West Kalimantan and fight for the nobility of the Malays, and serves as Islamic defenders in West Kalimantan.

Looking at the various religious affiliations that exist among Muslim social media users in Pontianak, there is a tendency that they are affiliated to radical organizations in their religious affiliation profiles directly or indirectly, This is in line with what Ro'uf ${ }^{28}$ claimed that Indonesia, since the reform era or post-new order era, has witnessed the development trend of mass organizations that carry the discourse of religious-based radicalism. According to him, the emergence of various Islamic movements was based on the same issues and narratives namely the struggle for "formalization of sharia" and the response to the failure of the western-style secular nationalist movement. However, there are also some Islamic movements respond to narratives of solidarity with fellow Muslims or issues that are developing in the international world.

\section{Religious Narratives}

Social media for Pontianak Muslim netizens is also actively used to discuss various religious issues that can be seen from their various posts on social media both in individual posts in the form of status and comments on other users' posts. Defending the Ulemas is a hot issue among Pontianak Muslim netizens. This issue is evident in the posts on the accounts of Habib M Iskandar Al-Kadri's Facebook page, Donny Iswara's, and several accounts that call for the issue of Defending the Ulemas and defending Muslims in each of their posts. One of Donny Iswara's posts on December 5, 2018, contained a

\footnotetext{
${ }^{27}$ Rizky Zulham, “Angkat Budaya Dan Marwah, Persatuan Orang Melayu Kalbar Akan Gelar Deklarasi,” March 3, 2017.

28 Abdul Mukti Ro'uf, "Mengurai Radikalisme Agama Di Indonesia Pasca Orde Baru," Ulumuna 11, no. 1 (November 2017): 157-76, https://doi.org/10.20414/ ujis.v11i1.425.
} 
narrative to defend Habib Bahar Bin Smith's lectures which are often perceived as harsh and containing hate speech. However, there are also Pontianak netizens who wrote counter-narratives by writing comments saying defending Habib Bahar is not supposed to be done as posted by Qodja Galata on December 8, 2018, on his Facebook account.

At the same time, the narrative of defending the Ughyur Muslims, which is viral on national social media is also circulating widely in the Pontianak netizens' network. This viral can be seen from the posts on the account "Nandar Rezky Ramdhan" on December 20, 2018, containing an invitation to defend Ughyur Muslims which was held on Friday, December 20, 2018, at the UNTAN Digulis Roundabout led by the West Kalimantan Malay People's Association. The same posting is also found on the Agus Setiadi Facebook Account of the chairman of West Kalimantan POM. West Kalimantan POM is also actively involved, through its social media account, in mass mobilization to voice rejection on the actions of the Multipurpose Ansor Front (Banser) that burned a flag bearing the Islamic shahada which was blamed as a flag belonging to the Hizbut-Tahrir group whose existence was banned by the government. On several social media accounts run by POM and its activists, they actively called the act of shahada flag burning carried out by the Banser defamation of the Tawhid. The POM then through its social media accounts, invited the community of Muslim Pontianak to defend the tawhid which was posted by Agus Setiadi on October 25, 2018.

The following examples indicate that the religious narratives that emerged and became a trending topic among the Pontianak Muslim community are religious narratives that are closely related to national issues which are currently becoming heated discussion on social and print media. A variety of posts show that the issues contain pros and cons. These responses circulate in the national discourse such as Habib Bahar ibn Smith topic as well as Uyghur Muslims oppressions. The influence of various national issues that also develop in social media among the Pontianaak Muslim netizens is inseparable from the function of social media as a means of communication that is different from mass media in general. Social media, as quoted in 
Watie $^{29}$ has social forces that greatly influence public opinion that develops in society. Supporting mass movements can be formed because of the strength of online media because the content of social media has proved to be able to shape the opinions, attitudes, and behaviour of the public. This phenomenon in the context of Pontianak Muslim netizens can be seen from the rise of discussions or posts that contain various religious issues that are being viral on social media which often lead to actions in the real world such as those carried out by POM to defend tawhid flag and the issue of oppression of Uyghur Muslims.

The Defend-the-Ulemas Action, Defend the Tawhid, and the Islamic solidarity action which have become the narrative of discussion among Pontianak Muslim Netizens is a continuation of the so-called discourse of "Islamic Populism" which lately has emerged as a continuation of the "Defend Islam Action" that occurred in 2016. The Defend Islam Movement and its derivatives are said to be part of the rise of 'Populism' among Indonesian Muslims. As Sholikhin quoted $^{30}$, populism itself is intended as a conditioning society to the majoritarianism mentality. It is described as oppressed and threatened by the power outside of them. Majoritarianism itself is a made-up idea, not essential. Islamic populism is also referred to as a group of people who are marginalized by the New Order regime which is divided into three class groups, namely farmers or working class who are poor because they are eroded by the industrialization process, the educated middle class but do not have a job, and small entrepreneurs whose capital is less competitive with the results oligarchy between the state and market. Those who have the social basis of the Muslim mass then arise and seek to seize the role of the state based on "religion" and "piety" called the rise of "Islamic population". ${ }^{31}$ Thus, the narrative

\footnotetext{
${ }^{29}$ Watie, "Komunikasi Dan Media Sosial."

${ }^{30}$ Sholikhin, "Gerakan Politik Islam Di Indonesia Pasca Aksi Bela Islam Jilid I, II Dan III."

31 Ahmad Rizky Mardhatilah Umar, "Melacak Akar Radikalisme Islam Di Indonesia," Jurnal Ilmu Sosial Dan Ilmu Politik 4, no. 2 (2010): 169-86, https://doi.org/https://doi.org/10.22146/jsp.10935.
} 
that develops among Pontianak Muslim netizens is inseparable from the development of the phenomenon of "Islamic populism" as a form of Islamic awakening on social media.

Various religious narratives that develop among Pontianak Muslim Netizens provide a fairly dominant space for various discourses and discourses that are carried by the so-called group "conservative Islam". This phenomenon can be seen from several issues that are often raised by social media accounts such as the fan page of "Da'wah Khatulistiwa" which is affiliated with the Indonesian Hizbut-Tahrir (HTI) organization. Netizens often bring up some issues on the account included narrations about HTI which is a banned organization, the importance of defending the 'Tawhid flag as a muslim' flag symbol, as well as the importance of upholding the caliphate, completing sharia practices, and other. Other variant forms are accounts that display narratives representing groups promoting "Islamic formalism" such as accounts affiliated with the Islamic Defenders Front and the Malay People's Association which often raise issues relating to the defence of some Islamic symbols such as 'Ulema' and 'Flag bearing the words of Tawhid'. Whereas Moderate groups are often represented by social media accounts affiliated with the Nahdlatul Ulama such as the "NU Khatulistiwa" which often posts the discourse of "Islam Nusantara" (Islam of the Archipelago), "Islam and Nationalism" and the importance of safeguarding the Unitary State of the Republic of Indonesia. ${ }^{32}$

The "Qodja Galata" account and the "Donny Iswara" account are types of accounts that actively voice various religious narratives with both pros and cons. These accounts can be grouped as Opinion Maker or Opinion Leader in communication theory. To become an opinion leader, as quoted from Syahputra ${ }^{33}$ it goes through at least two stages. The first stage, information or messages spread through the mass media are received by an opinion leader who has access to the

\footnotetext{
32 Basori, "Antara Budaya Dan Agama; Menegaskan Identitas Islam Nusantara," Madania 7, no. 1 (2017): 1-31.

33 Iswandi Syahputra, "Demokrasi Virtual Dan Perang Siber Di Media Sosial: Perspektif Netizen Indonesia," ASPIKOM 3, no. 3 (2017): 457-75.
} 
source of the information or messages. The second stage, information or messages received by an opinion leader is then spread to the public. In the context of social media, each account user can become an opinion leader or opinion-maker that influences his followers.

\section{Response to Trending Religious Issues in Social Media}

Many religious issues that develop in social media among Pontianak Muslims discussed in the previous section cannot be separated from the development trend of viral religious discourses in the media on a national scale. This issue can be seen from various issues such as the polemic of burning the tawhid flag, the campaign of defending Islam and defending the ulemas, the solidarity action for the Uyghur Muslim community in China. One of the supporting factors of the above argument is the massive social media accounts that actively participate in opinion-makers on various issues at the time. In addition, national trends in which religious issues are raised by Conservative Islamic circles such as the Islamic Defenders Front and Hizbut-Tahrir Indonesia also prevail among Pontianak muslim netizens, where opinion makers as mentioned in the previous section of this article actively participate in campaigns for these religious issues as a preference for each post on social media. In other words, religious issues circulating among Pontianak Muslim netizens are still monopolized by conservatives rather than moderate circles. This argument is the case with religious discourses on a national scale.

However, it is interesting to see the emergence of opinion makers who use ethnic and regional identities in responding to each developing religious issue. Accounts affiliated with the "Malay People's Association of West Kalimantan" are examples of accounts that carry Malay and Islamic identity in every action or campaign on religious issues that develop on social media. However, in general, the discourse they built are inseparable from religious issues that develop on a national scale that is still dominated by conservatives. On the other hand, religious issues raised by moderates do not get a positive response among Pontianak Muslim netizens. This issue happens because, in addition to the massive social media accounts that actively 
campaign for religious issues raised by the conservatives, on the one hand, there are still very few opinion leaders or opinion makers from moderate groups who actively participate in counter-campaigns on these issues.

\section{Conclusion}

The development of communication and information technology has brought an extraordinary impact on the changing social structure of its users. One of them is the emergence of social media as a means of communication that undeniably has also brought changes to the social structure and aspects of its users, including the religious identity discussed in this paper. Social media contributes to the shaping of religious identity among Muslim social media users in Pontianak. This indication can be seen from at least two aspects. First, it is the typology of social media users in the Pontianak Muslim community, and second is the trend of the religious identity of Muslim social media users in Pontianak. Second, Networkers, i.e. those who only use social media as a means to connect, and third, Netadvocates, i.e. those who consciously use the internet and social media as a means of conveying their ideas and thoughts related to developing religious issues.

Meanwhile, the trend of Pontianak Muslim netizens' religious identity can be seen from at least three aspects: first, their diverse religious affiliations and attachment to major religious organizations in Indonesia such as NU, FPI, and HTI. There are also religious affiliations related to specific ethnic groups, as in the case of the Malay Peoples' Association, which in general still tend to be conservative. Second, religious narratives among Pontianak Muslim netizens are mostly influenced by national religious issues such as defend the ulemas actions, defend tawhid actions and solidarity movements that spread widely among these netizens which indicates that religious narratives are still dominated by "conservative" groups rather than "moderate" circles. Third, Pontianak netizens still follow the trend of religious issues that develop at the national level resulting in similar response where the conservatives still dominate the narrative of social media discussion as opposed to the moderates. 


\section{Bibliography}

Abdullah, Irwan. "DI BAWAH BAYANG-BAYANG MEDIA: Kodifikasi, Divergensi, Dan Kooptasi Agama Di Era Internet." Sabda: Jurnal Kajian Kebudayaan 12, no. 2 (December 2017): 116-21. https://doi.org/10.14710/sabda.12.2.116-121.

Ardhianto, Imam. "Kontra Publik Keagamaan Dalam Media Baru: Islam, Kebudayaan Populer, Dan Media Sosial Pada Gerakan \#IndonesiaTanpaJIL." Antropologi Indonesia, no. 2 (2016): 83102.

Atkinson, J. "Qualitative Methods Book Title: Journey into Social Activism Book Subtitle: Qualitative Approaches This Chapter Explores :" Journey into Social Activism, 2017, 27-64.

Basit, Abdul. "Dakwah Cerdas Di Era Modern." Jurnal Komunikasi Islam 3, no. 1 (June 2013): 76-94. https://doi.org/10.15642/ jki.2013.3.1.\%p.

Basori. "Antara Budaya Dan Agama; Menegaskan Identitas Islam Nusantara." Madania 7, no. 1 (2017): 1-31.

Bennett, Liz. "Social Media, Academics' Identity Work and the Good Teacher." International Journal for Academic Development 22, no. 3 (July 2017): 245-56. https://doi.org/10.1080/1360144X. 2017.1305961.

Bertram, Luke. "Terrorism, the Internet and the Social Media Advantage: Exploring How Terrorist Organizations Exploit Aspects of the Internet, Social Media and How These Same Platforms Could Be Used to Counter-Violent Extremism." Journal for Deradicalization, no. 7 (2016): 225-52.

Fitriani, Yuni. "Analisis Pemanfaatan Berbagai Media Sosial Sebagai Sarana Penyebaran Informasi Bagi Masyarakat." Paradigma Jurnal Komputer Dan Informatika 19, no. 2 (October 2017): 14852. https://doi.org/10.31294/p.v19i2.2120.

Hasfi, Nurul, Sunyoto Usman, and Hedi Pudjo Santosa. "Representasi Kepemimpinan Calon Presiden Di Twitter." ASPIKOM 3, no. 2 (May 2017): 270-84.

Holik, Idham. "Teknologi Baru Media Dan Demokratisasi Di 
Indonesia.” Jurnal Makna 1, no. 2 (2011): 41-57. https://doi.org/ 10.33558/makna.v1i2.1060.

Isnin, Nadrawina. "Social Media, Religion, Gender and Politics in Malaysia: A Case of the Social Media Usage by Sarawak Muslim Female Candidates in Batang Sadong and Batang Lupar in the 2018 Malaysian General Election." Al-Albab; Vol 7, No 2 (2018): 161-172 DO - 10.24260/Alalbab.V7i2.1114, December 1, 2018. http://jurnaliainpontianak.or.id/index.php/alalbab/article/view/111 4.

Khamdan, Muh, and Wiharyani. "Mobilisasi Politik Identitas Dan Kontestasi Gerakan Fundamentalisme." Al-Tahrir 18, no. 1 (2018): 193-218.

Mujahidin, Anwar. "Umat Beragama Sebagai Masyarakat Beradab: Identitas Agama VS Kebangsaan.” Jurnal Kalam 9, no. 1 (2015): $17-30$.

Pakpahan, Roida. “Analisis Fenomena Hoax Di Media Sosial Dan Cara Menanggulangi Hoax." In Konferensi Nasional Ilmu Sosial Dan Teknologi, 479-84, 2017.

Putri, Sukma Ari Ragil. "Wacana Islam Populer Dan Kelahiran Ustaz Medsos Di Ruang Publik Era Digital." Jurnal Komunikasi Dan Kajian Media 2, no. 1 (2018): 87-114.

Rahadi, Dedi Rianto. "Perilaku Pengguna Dan Informasi Hoax Di Media Sosial." Jurnal Manajemen Dan Kewirausahaan 5, no. 1 (June 2017): 58-70.

Rahman, M.Syaiful. "Islam Dan Pluralisme." Fikrah 2, no. 1 (2014): 401-18.

Ro'uf, Abdul Mukti. "Mengurai Radikalisme Agama Di Indonesia Pasca Orde Baru." Ulumuna 11, no. 1 (November 2017): 157-76. https://doi.org/10.20414/ujis.v11i1.425.

Setiansah, Mite. "Smartphonisasi Agama: Transformasi Perilaku Beragama Perempuan Urban Di Era Digital." Komunikasi 10, no. 1 (2015): $1-10$.

Sholikhin, Ahmad. "Gerakan Politik Islam Di Indonesia Pasca Aksi Bela Islam Jilid I, II Dan III.” MADANI 10, no. 1 (2018): 12-33. Simangunsong, Benedictus A. "Interaksi Antarmanusia Melalui Media 
Sosial Facebook Mengenai Topik Keagamaan.” ASPIKOM 3, no. 1 (2016): 65-76.

Situmorang, James R. "Pemanfaatan Internet Sebagai New Media Dalam Bidang Politik, Bisnis, Pendidikan Dan Sosial Budaya." Administrasi Bisnis 8, no. 1 (2012): 73-87.

Stenius, Kerstin, Klaus M\%okel\%o, Michal MiovskyÏ, and Roman Gabrhell̀k. iHow to Write Publishable Qualitative Research." Publishing Addiction Science: A Guide for the Perplexed, 2017, 155-72. https://doi.org/10.5334/bbd.h.

Susilo, Budi. "Pemasaran Digital: Segmentasi Demografi Pengguna Media Sosial Di Kota Pontianak." Jurnal Eksplora Informatika 8, no. 1 (2018): 69-79. https://doi.org/10.30864/eksplora.v8i1.163.

Syahputra, Iswandi. "Demokrasi Virtual Dan Perang Siber Di Media Sosial: Perspektif Netizen Indonesia." ASPIKOM 3, no. 3 (2017): 457-75.

Thomas, Lisa, Pam Briggs, Andrew Hart, and Finola Kerrigan. "Understanding Social Media and Identity Work in Young People Transitioning to University." Computers in Human Behavior 76 (2017): 541-53. https://doi.org/https://doi.org/10.1016/j.chb.2017. 08.021 .

Umar, Ahmad Rizky Mardhatilah. "Melacak Akar Radikalisme Islam Di Indonesia." Jurnal Ilmu Sosial Dan Ilmu Politik 4, no. 2 (2010): 169-86. https://doi.org/10.22146/jsp.10935.

Wahyudi, Hijrah. "Analisis Faktor-Faktor Yang Dipertimbangkan Netizen Dalam Melakukan Transaksi E-Commerce Di Kota Pontianak." Jurnal Eksos 10, no. 1 (2006): 32-44.

Watie, Errika. D. S. "Komunikasi Dan Media Sosial." The Messenger 3, no. 1 (2011): 69-75.

Zulham, Rizky. "Angkat Budaya Dan Marwah, Persatuan Orang Melayu Kalbar Akan Gelar Deklarasi." March 3, 2017. 